\title{
An Investigation of the Values and Attitudes of Teachers Toward Teacher Accountability in China and Canada
}

\author{
Noel Hurley, Dandan Lu \\ Memorial University, St. John's, Canada
}

\author{
Robert Hurley \\ Université Laval, Quebec, Canada
}

\begin{abstract}
This paper presents a comparative study of teacher accountability between teachers in China and Canada. The investigation examined data using cultural and social differences toward accountability as a guide. A questionnaire developed was used to measure teacher dispositions toward internal (professional) accountability and external (bureaucratic) accountability and to determine if there were differences between teachers in the two countries, China and Canada. $T$-tests, analysis of variance (ANOVA), and other measures of central tendencies were used to analyze data in the Statistical Package for Social Sciences (SPSS) Version 20. Canadian teacher scores $(n=169)$ for external accountability $(M=4.55 ; S D=0.44)$ were higher than teacher scores for internal accountability $(M=3.81 ; S D=0.60)$. No differences between urban and rural areas were observed among Canadian teachers. Results showed that the means of external accountability $(M=4.13 ; S D=0.59)$ were higher than those of internal accountability $(M=3.59 ; S D=0.50)$ among Chinese teachers $(n=284)$. Canadian teacher scores were higher than Chinese teacher on both measures; the results for both external and internal accountability were found to be statistically significant. The differences suggest that further study and analyses are necessary to determine the cultural and educational implications of these differences.
\end{abstract}

Keywords: internal (professional) accountability, external (bureaucratic) accountability, high-stakes testing, Organization for Economic Cooperation and Development (OECD) testing programmes

\section{Introduction}

Kouzes and Posner (2011) contend that today's society has become increasingly critical of educational systems and places a higher demand for accountability of the system. To satisfy this critical demand, schools have employed strategies to increase accountability as a measure of school effectiveness. The connection seems to infer that the greater the level of accountability, the more effective schools will be. This logical connection is plagued with difficulty because of changes in value. Hoy and Miskel (2008) stated that "As preferences of constituencies change, constraints and expectations evolve to define school effectiveness do not remain constant" (p. 293). This becomes problematic because what makes for an effective school is often subject to change. The perception of what makes an effective school changes as societal values evolve. In recent history, there has been a transition from emphasis placed on the social and emotional growth of students to a present day emphasis on student achievement and accountability (Hoy \& Miskel, 2008). A further complicating matter

Noel Hurley, Ph.D., associate professor, Faculty of Education, Memorial University.

Dandan Lu, Ph.D. candidate, Faculty of Education, Memorial University.

Robert Hurley, Ph.D., professor, Faculte de Theologie, Université Laval. 
is that when public schools address societal trends, there will likely still be differences in opinions from stakeholders, as pointed out by Hoy and Miskel (2008), "Parents, administrators, students, teachers, school board members, businesspeople, policy makers, news media, and taxpayers prefer different and frequently conflicting effectiveness criteria" (p. 294).

Grissom, Nicholson-Crotty, and Harrington (2014) provided very recent evidence from the United States (U.S.) that holding teachers and schools directly accountable for their students' learning has little effect on increased student achievement. Their analysis of the No Child Left Behind (NCLB) legislation presents evidence that NCLB has had only small positive effects on student achievement. They presented evidence from studies by Haladyna, Haas, and Allison (1998) that there is a negative relationship between accountability and teachers' feelings about their work. Hoy and Miskel (2008) argued that "Using tests in accountability systems to determine whether the standards have been met and to evaluate school improvement initiatives generates considerable controversy" (p. 310). Murnane and Pappay (2010) stated that they had support for the principles for testing brought about by the NCLB program, but that they also had concern for the practices that were involved. The use of standardized tests in schools has also been linked to increased test anxiety which has a negative impact on students (Segool, Carlson, Goforth, Von der Embse, \& Barterian, 2013; Mulvenon, Stegman, \& Ritter, 2005). It can be inferred that teachers in this type of accountability system probably feel more stress than in a system in which no direct connection is made with student achievement testing.

The educational systems in the two study countries have some similarities to the American accountability system referenced above but many differences as well. Educational funding and resources are unequal in China among districts and between rural and urban areas, and more schools are needed particularly in rural and underdeveloped areas (Dello-Lacovo, 2009). Urban teachers are more stressed than their rural peers, and at the same time, their educational qualifications and salaries are better than rural teachers; urban parents' expectations are much higher than are those of rural parents and urban parents appear to hold the teachers to a higher level of accountability. There is a divide between urban and rural educational achievement that appears to be the result of the resource provision in both settings ( $\mathrm{Lu}, 2014)$. Hui (2012) contended that teachers' perceptions are influenced by socio-cultural norms. Cultural and policy practices policies adopted in East Asian countries may reflect cultural differences (Brown, Hui, Yu, \& Kennedy, 2011; Hui, 2012).

In Canada, the Constitution Acts of 1867 and 1981 gave responsibility for education to the provinces. This has resulted in the development of 10 different provincial systems of education with similar but somewhat differing governance and accountability systems. Two provinces, Ontario and British Columbia, have Colleges of Teachers that administer and oversee the teaching profession in each respective province. All provinces have similar licensing procedures and salary provisions that offer increasing remuneration that is tied to increasing educational levels and teaching experience. All provinces except for Ontario require teachers to have at least two undergraduate degrees and one graduate degree (either master's or doctorate) to obtain the highest certification level for salary determination. Teachers' unions in each jurisdiction in Canada have significant power, and membership is mandatory within the public schooling systems. Generally speaking, the greater the number of years one teaches and the higher one's educational level, then the greater remuneration one is paid in Canada (Hurley \& Reidel, 2000).

Recent study results of the Organization for Economic Cooperation and Development (OECD) countries indicate that Canada has one of the highest achieving public school systems in the world and that the between schools differences in Canada are among the lowest in the world (Parulekar, 2009; Council of Ministers of 
Education, Canada, 2014). Parulekar (2009) argued that the Canadian system arguably has one of the world's most effective public schooling systems as it excels in both excellence and equity measures. The Programme for International Student Assessment (PISA) (2014) provided evidence that no matter where one attends public school in Canada that students are likely to have effective public schooling characterized by high achievement levels. Thus, while Canadians can be assured of an adequate public education, no matter where they live in Canada, Chinese students on the other hand are less likely in rural areas to receive a public school education equivalent to their urban counterparts. We are interested in investigating if teachers in the two countries with vastly different schooling conditions have different perceptions on how they are held accountable or how they hold themselves accountable for their job performances as teachers.

\section{Study Objective}

This study investigated and compared the dispositions of Canadian and Chinese teachers toward teacher accountability. We investigated the differences between teachers who were teaching at the high school level in both countries. Our Canadian sample used data collected in an Eastern Canadian province; our sample will be updated to include data gathered in two other provinces. Chinese data were collected from teachers who were teaching before the reforms that transformed the system from the traditional examination-oriented system to a quality-oriented system and from teachers who began teaching after the reforms. The study sought to identify any differences related to the demographic factors that were operationalized in the study.

\section{Research Questions}

The present study investigated the following five research questions:

1. What are Chinese teachers' perceptions toward external accountability (bureaucratic)?

2. What are Chinese teachers' perceptions toward internal accountability (professional)?

3. What are Canadian teachers' perceptions toward external accountability (bureaucratic)?

4. What are Canadian teachers' perceptions toward internal accountability (professional)?

5. What are the differences between Canadian and Chinese teachers on each measure?

\section{Methods}

\section{Instruments}

The study investigated teacher accountability disposition including internal and external accountability using a questionnaire that was developed by Rosenblatt (2013) (see Appendix). The Rosenblatt survey also investigated cultural values, including individualism and collectivism based on previous work by Triandis and Gelfand (1998). For the present study, we have only analyzed the indicators that seek to measure teachers' dispositions toward internal (professional) accountability and external (bureaucratic) accountability. We have compared the results from both countries to determine if there are any significant differences between Chinese teachers and Canadian teachers in their responses on items designed to measure accountability dispositions. We used $t$-tests, analyses of variance (ANOVA), and other measures of central tendencies to compare teacher responses from the two countries. Analyses were conducted using the Statistical Package for Social Sciences (SPSS) Version 20.

\section{Research Sample}

The study sample included 284 secondary teachers from urban and rural areas throughout China. Data were gathered in a number of settings in China and included surveys of teachers from several different 
provinces and some who were teaching before the market reforms and some who began teaching after the reforms. Data have been gathered from several Canadian provinces but data from only one province are retained as the most recently gathered surveys have yet to be coded for analysis. For the purposes of this study, 130 high school teachers have been surveyed from urban and rural schools in an Eastern Canadian province.

\section{Results}

Results showed that the means of external accountability $(M=4.13 ; S D=0.59)$ were higher than those of internal accountability $(M=3.59 ; S D=0.50)$ among Chinese teachers. Independent $t$-tests were performed on external and internal accountability measures by location of schools. The results for both external and internal accountability were found to be statistically significant. Analysis by geographic location showed that urban teachers scored higher $(3.65 ; S D=0.49)$ on external accountability than rural teachers $(3.39 ; S D=0.50$; $t=2.20 ; p<0.05)$. Table 1 shows that the measures were reliable for the Chinese data in that the Cronbach's alpha scores all were greater than 0.8 .

Table 1

Reliability Coefficients: Chinese Teachers' Accountability Variables

\begin{tabular}{lll}
\hline Scale & Number of items & Cronbach's alpha \\
\hline External accountability (bureaucratic) & 13 & 0.839 \\
Internal accountability (professional) & 7 & 0.810 \\
Attitudes towards accountability_School administration & 7 & 0.818 \\
Attitudes towards accountability_Parents & 7 & 0.840 \\
\hline
\end{tabular}

Note. Source: Lu (2014).

Questions from the Rosenblatt survey that were used to determine teachers' perceptions toward external accountability for Chinese and Canadian teachers can be seen in Tables 2, 3, 4, and 5. Means and standard deviations for Canadian teachers' responses for both internal and external accountability can be seen in Tables 3 and 5. Table 6 provides evidence that the Canadian data were also reliable for the four scales that were retained as each score exceeded 0.8 similarly to the Chinese data.

Table 2

Chinese Teachers' External (Bureaucratic) Accountability $(N=284)$

\begin{tabular}{lll}
\hline In your work as a teacher, to what extent do you feel that it is your responsibility to: & $M$ & $S D$ \\
\hline Q1. Make sure your students achieve high achievement scores & 3.91 & 0.887 \\
Q2. Meet expected standards & 3.73 & 0.768 \\
Q3. Be accountable for your students achievements & 3.91 & 0.935 \\
Q4. Report to school leadership on the way you perform your work & 3.31 & 1.068 \\
Q5. Report to other teachers on the way you perform your work & 2.98 & 1.165 \\
Q6. Report to parents on the way you perform your work & 3.52 & 1.068 \\
Q7. Allow your work in class to be transparent to school leadership & 3.57 & 0.989 \\
Q8. Allow your work in class to be transparent to other teachers & 3.61 & 1.120 \\
Q9. Allow your work in class to be transparent to parents & 3.60 & 1.117 \\
Q10. Be evaluated on the basis of your work achievement & 3.79 & 1.007 \\
Q11. Change your work according to feedback you get & 4.05 & 0.837 \\
Q12. Be held accountable when your work in the classroom does not meet expectations & 3.81 & 0.940 \\
Q13. Be acknowledged for the success of your classes & 3.84 & 0.973
\end{tabular}

Note. Source: Lu (2014). 
Table 3

Canadian Teachers' External (Bureaucratic) Accountability $(N=169)$

\begin{tabular}{lll}
\hline In your work as a teacher, to what extent do you feel that it is your responsibility to: & $M$ & $S D$ \\
\hline Q1. Make sure your students achieve high achievement scores & 4.01 & 0.87 \\
Q2. Meet expected standards & 4.01 & 0.81 \\
Q3. Be accountable for your students achievements & 3.94 & 0.89 \\
Q4. Report to school leadership on the way you perform your work & 3.34 & 1.05 \\
Q5. Report to other teachers on the way you perform your work & 3.01 & 1.11 \\
Q6. Report to parents on the way you perform your work & 3.48 & 1.08 \\
Q7. Allow your work in class to be transparent to school leadership & 3.89 & 0.99 \\
Q8. Allow your work in class to be transparent to other teachers & 3.70 & 1.06 \\
Q9. Allow your work in class to be transparent to parents & 3.74 & 1.07 \\
Q10. Be evaluated on the basis of your work achievement & 3.66 & 1.06 \\
Q11. Change your work according to feedback you get & 4.08 & 0.85 \\
Q12. Be held accountable when your work in the classroom does not meet expectations & 3.90 & 0.92 \\
Q13. Be acknowledged for the success of your classes & 3.69 & 1.04
\end{tabular}

Table 4

Chinese Internal (Professional) Accountability $(N=284)$

\begin{tabular}{lll}
\hline In your work as a teacher, to what extent do you feel that it is your duty to: & $M$ & $S D$ \\
\hline Q14. Achieve professional goals & 3.92 & 0.906 \\
Q15. Develop professionally (training sessions, workshops, conferences, etc.) & 3.36 & 1.062 \\
Q16. Learn from the work of outstanding colleagues & 3.99 & 0.886 \\
Q17. Be responsible for teaching in the best possible way & 4.42 & 0.764 \\
Q18. Be responsible for using professional knowledge in your work & 4.27 & 0.836 \\
Q19. Be accountable to your own inner moral standards & 4.54 & 0.700 \\
Q20. Be accountable to professional ethics & 4.51 & 0.726
\end{tabular}

Note. Source: Lu (2014).

Table 5

Canadian Teachers' Internal (Professional) Accountability $(N=169)$

\begin{tabular}{lll}
\hline In your work as a teacher, to what extent do you feel that it is your duty to: & $M$ & $S D$ \\
\hline Q14. Achieve professional goals & 4.48 & 0.651 \\
Q15. Develop professionally (training sessions, workshops, conferences, etc.) & 4.37 & 0.792 \\
Q16. Learn from the work of outstanding colleagues & 4.35 & 0.740 \\
Q17. Be responsible for teaching in the best possible way & 4.72 & 0.491 \\
Q18. Be responsible for using professional knowledge in your work & 4.59 & 0.626 \\
Q19. Be accountable to your own inner moral standards & 4.63 & 0.618 \\
Q20. Be accountable to professional ethics & 4.81 & 0.393 \\
\hline
\end{tabular}

Table 6

Reliability Coefficients: Canadian Teachers' Accountability Variables

\begin{tabular}{lll}
\hline Scale & Number of items & Cronbach's alpha \\
\hline External accountability (bureaucratic) & 13 & 0.883 \\
Internal accountability (professional) & 7 & 0.829 \\
Attitudes towards accountability_School administration & 7 & 0.836 \\
Attitudes towards accountability_Parents & 7 & 0.880 \\
\hline
\end{tabular}


The means, standard deviations, and significant differences for responses made by gender, age, geography, school level, teaching area, and leadership role of the sample of Chinese teachers were calculated for external accountability (bureaucratic). It was hoped to determine the perceptions of Chinese teachers toward external accountability (bureaucratic). The findings indicate that Chinese teachers believe that they are held accountable from an external accountability perspective. An ANOVA did not identify any significant differences among demographic variables on this measure except for urban and rural status.

Schlenker and Weigold (1989) introduced the notion of self-accountability, stating that it pertained to internal mechanisms, such as personal values and ethics. Rosenblatt (2013) indicated that these mechanisms provided inner standards for individuals. She further stated that compared to external accountability that internal accountability would typically represent a response to the professional wisdom and ethics of educators. The seven items that include a range of responses from 1 ("Very little extent") to 5 ("Very large extent") in this section of her survey are consistent with this definition. A set of seven items was designed to seek teacher perceptions along this dimension.

Chinese teachers' responses to questions concerning internal (professional) accountability provide evidence that they hold themselves highly accountable on all aspects of these survey items. Their responses show that they feel a responsibility to achieve professional goals, develop professionally, learn from colleagues, teach in the best possible way, use professional knowledge, and be accountable to teachers' own inner moral standards and professional ethics, especially inner moral standards and professional ethics $(M>4.5)$ (see Table 4). Most participants chose "Agree" or "Strongly agree" to answer Question 19 "Be accountable your own inner moral standards" and Question 20 "be accountable to professional ethics." That the standard deviations of these two questions $(S D=0.700$ and $S D=0.724)$ are less than those of other items indicates that the teachers' answers on these two items are more consistently proffered by teachers.

It can be seen in Tables 4 and 5 that Canadian teachers had higher mean scores on every item that measured professional accountability. For Canadian teachers, teacher scores for external accountability $(M=4.55 ; S D=0.44)$ were higher than teacher scores for internal accountability $(M=3.81 ; S D=0.60)$. No differences between urban and rural areas were observed among Canadian teachers. The larger the school in the Canadian sample, the higher were the teacher scores on external accountability measures. An ANOVA that looked at school size and internal and external accountability among Canadian teachers produced a significant difference related to school size at a significance level of $p<0.001$.

A comparison of results from the two country sample produced some significant differences on a number of the individual items for external accountability. ANOVA results between the two countries produced significantly higher scores for Canada on five of the 12 items. The items "Meet expected standards," "Allow your work in class to be transparent to school leadership," "Allow your work in class to be transparent to other teachers," "Allow your work in class to be transparent to parents," and "Be evaluated on the basis of your work achievement" all produced statistically significant results.

An ANOVA completed on the internal accountability also produced a number of statistically significant differences between the two country samples. The questionnaire items "Achieve professional goals," "Develop professionally," "Learn from the work of outstanding colleagues," "Be responsible for teaching in the best possible way," "Be responsible for using professional knowledge in your work," "Be accountable to professional ethics," "Strive to achieve set goals," and "Report on your performance regarding academic achievements" each produced statistically significant differences between the Canadian and Chinese samples. 
An examination of individual item responses on both internal (professional) accountability and external (bureaucratic) accountability produced a trend of higher responses from Canadian teachers that were significantly different from their Chinese counterparts (see Tables 2, 3, 4, and 5). Under external (bureaucratic) accountability measures, teachers in Canada felt more responsibility toward meeting expected standards than did Chinese teachers. Canadian teachers were also more willing to let their work in class be transparent to school leadership, were willing to allow their work to be transparent to other teachers, transparent to parents, to be evaluated on their work achievement, and to be acknowledged for the success of their classes than were Chinese teachers.

Measures for internal (professional) accountability (see Tables 4 and 5) also produced higher scores for Canadian teachers than Chinese teachers on nearly all retained indicators. Statistically significant differences were noted for achieving professional goals, developing professionally, learning from the work of outstanding colleagues, being responsible for teaching in the best way possible, being responsible for using professional knowledge in your work, being accountable to professional ethics, striving to achieve set goals, and being acknowledged for success in their classes. Possible reasons for these findings are offered in the next section.

\section{Discussion of Findings}

The findings that Canadian teachers produced higher values for many of the item responses measuring both internal and external accountability were partially unexpected from a socio-cultural perspective. While the internal accountability measures were not expected to be greatly different, there was an expectation that given the differences existing in the governance structures in each country and the huge differences in population that there would be more bureaucratic control in the Chinese system. The finding that Canadian teachers perceive higher bureaucratic accountability within their system than is perceived within the Chinese system was somewhat surprising until one critically examines the environment where the surveys were completed. It is our belief that this finding cannot be generalized to the Canadian population as the data for this paper were gathered in only one province that has in recent years demonstrated very centralized control that is not present in most other Canadian provinces. ${ }^{1}$ The finding that teachers are more bureaucratically accountable than teachers in a system that is reputed to be challenged when human rights are considered is not the kind of finding that one wants to see in a representative democracy that prides itself on being socially just.

These perceptions of Canadian teachers being externally accountable do not seem to have a negative effect on their attitudes toward their job performance as they hold themselves to a high level of internal accountability. One could speculate that if the bureaucratic oversight was causing much anxiety in teachers that their desire to be professionally responsible might be negatively impacted. A factor that might make teachers more willing to be externally accountable is that the Canadian provinces all pursue approaches to their teachers that have few negative ramifications for failure of their students to achieve expected standards. The reason for that might be the result of consistently high public school performance on national and international assessments of public school student achievement. Canadian jurisdictions (provinces) have not adopted the kind of direct accountability of teachers for their student achievement on external testing as seen in the U.S. under their NCLB legislation or in other countries with similar approaches to accountability of teachers. External tests in Canadian public school

\footnotetext{
${ }^{1}$ Data were collected in a province that abolished all school boards except for one in each language. The generally held public perception is that this action was taken to centralize control at the provincial government level. We have gathered data from two other Canadian provinces that will add to generalizability to the Canadian population.
} 
jurisdictions are for the most part criterion referenced and results are used to measure students against the outcomes they are expected to learn. Test results are mostly used by schools and school districts to intervene in student learning. Identified weaknesses are addressed to ensure that learning outcomes incremental to the next level of learning are attained by students. This professional approach to how test results are handled might have a positive effect on teachers' perceptions toward holding themselves professionally accountable.

Study results add to understanding the unique contribution of Chinese cultural values on teacher accountability, and may help in the future to better understand accountability disposition in ethnic sub-cultures of this giant country. The disparity between urban and rural areas was one of the most significant findings of the survey of Chinese teachers. There was a significant different between rural teachers and urban teachers' perceptions about whether or not they were being acknowledged. Rural teachers felt that their chances of being acknowledged for the success of their classes were less the expectations of their urban peers. The fact that rural teachers earn less than urban teachers (Liu \& Onwuegbuzie, 2012), often rural teachers' salaries are often only half or less than urban teachers' salaries, might make rural teachers feel less need to be accountable. Incremental increases for rural teachers when they obtain additional qualifications are also much less than for urban teachers. Researchers claim that this is related to unequal educational funding between rural and urban areas in China, with urban areas having more favourable resource provision (Lin \& Zhang, 2006; Dello-Lacovo, 2009; Cheng, 2009; Liu \& Onwuegbuzie, 2012).

Educational policies are recognized as having a strong urban bias (Liu \& Onwuegbuzie, 2012). Urban teachers have more opportunities as more conferences on teaching and learning are available to them. $\mathrm{Lu}(2014)$ contended that most top schools are located in cities. Teachers who work in urban areas have students who have higher test results on external measures of academic performance. Urban students also have more chance to receive incidental learning from exposure to social and cultural activities in their everyday environment.

Liu and Onwuebgbuzie (2012) stated that rural Chinese teachers do not get as much parental support as urban teachers get. Generally, urban parents have better educational backgrounds than rural parents and they can afford to give their children more years of education and increased support for learning. Lu (2014) claimed that urban parents want more communication with teachers, they want to know how their children are performing, and to collaborate with teachers to better educate their children.

Even though many young rural people work in cities, now they still put their children in schools in their hometown with grandparents or other relatives. Lu (2014) contended that to provide for the care of these children on a daily basis that rural teachers have to take on more workload without much acknowledgement or encouragement from parents since it is not easy to meet the parents who work in cities far away. Liu and Onwuegbuzie (2012) supported Lu's opinion in this with a quote from a rural teacher who stated "... I do not get much support from parents. It seems that students study only for me." These authors provide recent evidence that educational inequality is still a problem in present day China.

\section{Conclusion}

These early findings of an ongoing and larger study of teacher accountability have provided a first comparison of teachers' dispositions within the two countries. As more data are gathered in both countries, we hope to continue to add to knowledge of teachers' attitudes toward how they are being held accountable externally and how they hold themselves internally accountable. From the present study, a number of observations can be made about differences between the two countries. Canadian teachers perceive that they are 
more bureaucratically accountable than Chinese teachers feel that they are being held accountable. In the Canadian study provinces, teachers are experiencing differing but stressful impacts on their working lives. Newfoundland eliminated local school governance, Nova Scotia had several years of funding cutbacks, and Ontario teachers were involved in a job action while data were being gathered. Lu (2014) contended that Chinese teachers tend not to state things superlatively. She said that teachers in China might want to state a "Strongly disagree" response but often refrain from doing so to prevent them from standing out among the crowd. Thus, we perhaps had a case where Chinese teachers understate their feelings. One strong recommendation that can be made from the present study is that future research should investigate the effect that cultural differences between the two countries have on the overall findings of teacher dispositions toward teacher accountability in the two countries.

\section{References}

Brown, G. T. L., Hui, S. K. F., Yu, F. W. M., \& Kennedy, K. J. (2011). Teachers' conceptions of assessment in Chinese contexts: A tripartite model of accountability, improvement, and irrelevance. International Journal of Educational Research, 50(5-6), 307-320.

Council of Ministers of Education, Canada. (2014). Education at a glance 2014: OECD indicators. Ottawa, Canada: Council of Ministers of Education.

Dello-lacovo, B. (2009). Curriculum reform and "quality education" in China: An overview. International Journal of Educational Development, 29, 241-249.

Grissom, J., Nicholson-Crotty, S., \& Harrington, J. (2014, December). Estimating the effects of No Child Left Behind on teachers' work environments and job attitudes. Educational Evaluation and Policy Analysis, 36(4), 417-436.

Haladyna, T., Haas, N., \& Allison, J. (1998). Continuing tensions in standardized testing. Childhood Education, 74(5), $262-273$.

Hoy, W., \& Miskel, C. G. (2008). Educational administration: Theory research and practice (8th ed.). New York, N.Y.: McGraw-Hill International Edition.

Hui, S. K. F. (2012). Missing conceptions of assessment: Qualitative studies with Hong Kong curriculum leaders. The Asia-Pacific Education Researcher, 21(2), 375-383.

Hurley, N., \& Reidel, H. (2000, April). Bill 160: The new educational funding model in Ontario: Cost control versus good pedagogy. Annual Conference of the American Educational Research Association, Chicago, I.L..

Kouzes, J. M., \& Posner, B. Z. (2011). Credibility: How leaders gain and lose it, why people demand it. San Francisco, C.A.: Jossey-Bass.

Liu, S., \& Onwuegbuzie, A. J. (2012). Chinese teachers' work tress and their turnover intention. International Journal of Educational Research, 53, 160-170.

Lu, D. (2014). An investigation of the values and attitudes of Chinese teachers toward teacher accountability in China (Master's thesis, Memorial University of Newfoundland, St. John's, Canada).

Mulvenon, S. W., Stegman, C. E., \& Ritter, G. (2005). Test anxiety: A multi-faceted study on the perceptions of teachers, principals, teachers, students, and parents. International Journal of Testing, 5(1), 37-61.

Murnane, R. J., \& Pappay, J. P. (2010). Teachers' views of No Child Left Behind: Support for the principles, concern for the practices. Journal of Economic Prospects, 24(3), 151-166.

Parulekar, P. (2009). Education and the competitive advantage of nations: Governance, achievement and economics. St. John's, N.L.: Atlantic School Boards' Association.

Programme for International Student Assessment (PISA). (2014). Paris, France: Organization for Economic Cooperation and Development.

Schlenker, B. R., \& Weigold, M. F. (1989). Self-identification and accountability. In R. A. Giacalone, \& P. Rosenfeld (Eds.), Impression management in the organization ( pp. 21-43). Hillsdale, N.J.: Earlbaum.

Segool, N., Carlson, J., Goforth, A., Von der Embse, N., \& Barterian, J. (2013). Heightened test anxiety among young children: Students' anxious responses to high stakes testing. Psychology in the Schools, 50(5), 489-499.

Triandis, H., \& Gelfand, M. (1998). Converging measurement of horizontal and vertical individualism and collectivism. Journal of Personality and Social Psychology, 74, 118-128. 


\section{Appendix: Teacher Accountability Questionnaire}

School code:

\section{Part A. Demographic Background}

Gender: $\square$ Male $\square$ Female

Age: (yrs)

Experience as a teacher: (yrs)

Tenure (permanent position): $\square$ Yes $\quad \square$ No $\quad \square$ Not relevant

If applicable, please specify which leadership position you hold in addition to teaching (e.g., vice-principal, headmaster, and subject-area coordinator):

Teaching area:

$\square$ Humanities, languages, and social studies

$\square$ Science, mathematics, and technology

$\square$ Arts and sport

$\square$ Other

Size of school in number of students:

School location: $\square$ Urban $\square$ Suburban $\square$ Rural $\square$ Other

School level: $\square$ Elementary/primary $\square$ Middle $\square$ High/secondary

School religion: $\square$ Secular $\square$ Religious

Teaching certificate level

Highest degree completed: $\square$ Bachelor $\quad \square$ Master $\square$ Doctoral

Part B. In Your Work as a Teacher, to What Extent Do You Feel That It Is Your Responsibility to

\begin{tabular}{|l|l|l|l|l|l|l|}
\hline \multicolumn{2}{|l|}{} & $\begin{array}{l}\text { Very } \\
\text { little }\end{array}$ & $\begin{array}{l}\text { Little } \\
\text { extent }\end{array}$ & $\begin{array}{l}\text { Neither little } \\
\text { nor large }\end{array}$ & $\begin{array}{l}\text { Large } \\
\text { extent }\end{array}$ & $\begin{array}{l}\text { Very large } \\
\text { extent }\end{array}$ \\
\hline 1 & Make sure your students achieve high achievement scores & 1 & 2 & 3 & 4 & 5 \\
\hline 2 & Meet expected standards & 1 & 2 & 3 & 4 & 5 \\
\hline 3 & Be accountable for your students achievements & 1 & 2 & 3 & 4 & 5 \\
\hline 4 & Report to school leadership on the way you perform your work & 1 & 2 & 3 & 4 & 5 \\
\hline 5 & Report to other teachers on the way you perform your work & 1 & 2 & 3 & 4 & 5 \\
\hline 6 & Report to parents on the way you perform your work & 1 & 2 & 3 & 4 & 5 \\
\hline 7 & Allow your work in class to be transparent to school leadership & 1 & 2 & 3 & 4 & 5 \\
\hline 8 & Allow your work in class to be transparent to other teachers & 1 & 2 & 3 & 4 & 5 \\
\hline 9 & Allow your work in class to be transparent to parents & 1 & 2 & 3 & 4 & 5 \\
\hline 10 & Be evaluated on the basis of your work achievements & 1 & 2 & 3 & 4 & 5 \\
\hline 11 & Change your work according to feedback you receive & 1 & 2 & 3 & 4 & 5 \\
\hline 12 & $\begin{array}{l}\text { Be held accountable when your work in the classroom does not meet } \\
\text { expectations }\end{array}$ & 1 & 2 & 3 & 4 & 5 \\
\hline 13 & Be acknowledged for the success of your classes & 1 & 2 & 3 & 4 & 5 \\
\hline
\end{tabular}


Part C. In Your Work as a Teacher, to What Extent Do You Feel That It Is Your Duty to

\begin{tabular}{|l|l|l|l|l|l|l|}
\hline \multicolumn{2}{|l|}{} & $\begin{array}{l}\text { Very } \\
\text { little }\end{array}$ & Little & $\begin{array}{l}\text { Neither little } \\
\text { nor much }\end{array}$ & Much & $\begin{array}{l}\text { Very } \\
\text { much }\end{array}$ \\
\hline 14 & Achieve professional goals & 1 & 2 & 3 & 4 & 5 \\
\hline 15 & Develop professionally (training sessions, workshops, conferences, etc.) & 1 & 2 & 3 & 4 & 5 \\
\hline 16 & Learn from the work of outstanding colleagues & 1 & 2 & 3 & 4 & 5 \\
\hline 17 & Be responsible for teaching in the best possible way & 1 & 2 & 3 & 4 & 5 \\
\hline 18 & Be responsible for using professional knowledge in your work & 1 & 2 & 3 & 4 & 5 \\
\hline 19 & Be accountable to your own inner moral standards & 1 & 2 & 3 & 4 & 5 \\
\hline 20 & Be accountable to professional ethics & 1 & 2 & 3 & 4 & 5 \\
\hline
\end{tabular}

Part D. To What Extent Do You Believe Your Work Should Include the Following Behaviours and Activities With Regard to School Management and Parents?

\begin{tabular}{|c|c|c|c|c|c|c|c|c|c|c|c|}
\hline & & \multicolumn{5}{|c|}{ School management } & \multicolumn{5}{|c|}{ Parents } \\
\hline & & $\begin{array}{l}\text { Very } \\
\text { little }\end{array}$ & Little & $\begin{array}{l}\text { Neither } \\
\text { little nor } \\
\text { much }\end{array}$ & Much & $\begin{array}{l}\text { Very } \\
\text { much }\end{array}$ & $\begin{array}{l}\text { Very } \\
\text { little }\end{array}$ & Little & $\begin{array}{l}\text { Neither } \\
\text { little nor } \\
\text { much }\end{array}$ & Much & $\begin{array}{l}\text { Very } \\
\text { much }\end{array}$ \\
\hline 21 & Strive to achieve set goals & 1 & 2 & 3 & 4 & 5 & 1 & 2 & 3 & 4 & 5 \\
\hline 22 & $\begin{array}{l}\text { Report on your performance regarding } \\
\text { students' academic achievements }\end{array}$ & 1 & 2 & 3 & 4 & 5 & 1 & 2 & 3 & 4 & 5 \\
\hline 23 & $\begin{array}{l}\text { Report on performance regarding curriculum } \\
\text { coverage }\end{array}$ & 1 & 2 & 3 & 4 & 5 & 1 & 2 & 3 & 4 & 5 \\
\hline 24 & $\begin{array}{l}\text { Report on performance regarding social } \\
\text { climate (e.g., student behavior and } \\
\text { discipline) in class }\end{array}$ & 1 & 2 & 3 & 4 & 5 & 1 & 2 & 3 & 4 & 5 \\
\hline 25 & Show transparency in your work & 1 & 2 & 3 & 4 & 5 & 1 & 2 & 3 & 4 & 5 \\
\hline 26 & $\begin{array}{l}\text { Get formal evaluations on the results of your } \\
\text { work }\end{array}$ & 1 & 2 & 3 & 4 & 5 & 1 & 2 & 3 & 4 & 5 \\
\hline 27 & Get feedback on your teaching & 1 & 2 & 3 & 4 & 5 & 1 & 2 & 3 & 4 & 5 \\
\hline
\end{tabular}

Part E. Please Indicate How Much You Agree or Disagree With the Following Statements About Your Work?

\begin{tabular}{|c|c|c|c|c|c|c|}
\hline & & $\begin{array}{l}\text { Strongly } \\
\text { disagree }\end{array}$ & Disagree & $\begin{array}{l}\text { Neither agree } \\
\text { nor disagree }\end{array}$ & Agree & $\begin{array}{l}\text { Strongly } \\
\text { agree }\end{array}$ \\
\hline 28 & $\begin{array}{l}\text { The way I teach in my class is determined for the most part by } \\
\text { myself. }\end{array}$ & 1 & 2 & 3 & 4 & 5 \\
\hline 29 & The contents taught in my class are those that I select myself. & 1 & 2 & 3 & 4 & 5 \\
\hline 30 & My teaching focuses on goals and objectives that I select myself. & 1 & 2 & 3 & 4 & 5 \\
\hline 31 & I myself select the teaching materials that I use with my students. & 1 & 2 & 3 & 4 & 5 \\
\hline 32 & I am free to be creative in my teaching approach. & 1 & 2 & 3 & 4 & 5 \\
\hline 33 & My job does not allow for much discretion on my part. & 1 & 2 & 3 & 4 & 5 \\
\hline 34 & In my class, I have little control over how classroom space is used. & 1 & 2 & 3 & 4 & 5 \\
\hline 35 & My school management strongly support my goals and values. & 1 & 2 & 3 & 4 & 5 \\
\hline 36 & My school administration values my contribution. & 1 & 2 & 3 & 4 & 5 \\
\hline 37 & $\begin{array}{l}\text { My school administration takes pride in my accomplishments at } \\
\text { work. }\end{array}$ & 1 & 2 & 3 & 4 & 5 \\
\hline 38 & My school administration really cares about me. & 1 & 2 & 3 & 4 & 5 \\
\hline 39 & $\begin{array}{l}\text { If given the chance, my school administration would take unfair } \\
\text { advantage of me. }\end{array}$ & 1 & 2 & 3 & 4 & 5 \\
\hline 40 & $\begin{array}{l}\text { My school administration is willing to help me when I need a } \\
\text { special favor. }\end{array}$ & 1 & 2 & 3 & 4 & 5 \\
\hline 41 & $\begin{array}{l}\text { Upon my request, my school administration would change my } \\
\text { working conditions, if this is at all possible. }\end{array}$ & 1 & 2 & 3 & 4 & 5 \\
\hline 42 & My school administration would ignore any complaint from me. & 1 & 2 & 3 & 4 & 5 \\
\hline
\end{tabular}


Part F. The Following Items Refer to Your Personal Values and Attitudes Toward Work and Life in General. Please Indicate How Much You Agree or Disagree With the Following Statements.

\begin{tabular}{|l|l|l|l|l|l|l|}
\hline \multicolumn{2}{|l|}{} & $\begin{array}{l}\text { Strongly } \\
\text { disagree }\end{array}$ & Disagree & $\begin{array}{l}\text { Neither agree } \\
\text { nor disagree }\end{array}$ & $\begin{array}{l}\text { Agree } \\
\text { agree }\end{array}$ \\
\hline 43 & I would rather depend on myself than on others. & 1 & 2 & 3 & 4 & 5 \\
\hline 45 & I rely on myself more than on others most of the time. & 1 & 2 & 3 & 4 & 5 \\
\hline 46 & I often do “my own thing." & 1 & 2 & 3 & 4 & 5 \\
\hline 47 & If a personal identity, independent of others, is very important to me. & 1 & 2 & 3 & 4 & 5 \\
\hline 48 & The well-being of my fellow teachers is important to me. & 1 & 2 & 3 & 4 & 5 \\
\hline 49 & I take pleasure in spending time with others. & 1 & 2 & 3 & 4 & 5 \\
\hline 50 & I feel good when I cooperate with others. & 1 & 2 & 3 & 4 & 5 \\
\hline 51 & $\begin{array}{l}\text { I believe that a person's influence is based primarily on his or her } \\
\text { ability and contribution to the society, and not on the authority of } \\
\text { his or her position. }\end{array}$ & 1 & 2 & 3 & 5 & 5 \\
\hline 52 & $\begin{array}{l}\text { I believe that followers are expected to obey their leaders without } \\
\text { reservation, rather than question their leaders when in disagreement. }\end{array}$ & 1 & 2 & 3 & 4 & 5 \\
\hline 53 & $\begin{array}{l}\text { I believe that people in positions of power try to increase their } \\
\text { social distance (hierarchical space) from less powerful individuals. }\end{array}$ & 1 & 2 & 3 & 5 \\
\hline 54 & $\begin{array}{l}\text { I believe that rank and hierarchical position should go with special } \\
\text { privileges. }\end{array}$ & 1 & 2 & 3 & 4 & 5 \\
\hline 55 & $\begin{array}{l}\text { I find orderliness and consistency more important than } \\
\text { experimentation or innovation. }\end{array}$ & 1 & 2 & 3 & 4 & 5 \\
\hline 56 & I tend to lead a highly structured life with few unexpected events. & 1 & 2 & 3 & 4 \\
\hline 57 & $\begin{array}{l}\text { When I have to do something, I prefer to receive instructions that } \\
\text { are spelled out in detail, so that I know what I am expected to do. }\end{array}$ & 1 & 2 & 3 & 5 \\
\hline 58 & $\begin{array}{l}\text { I like to live with laws that cover almost all situations (rather than } \\
\text { very few situations). }\end{array}$ & 1 & 2 & 3 & 5 \\
\hline
\end{tabular}

